NBER WORKING PAPER SERIES

IMPLICATIONS OF CORPORATE INDEBTEDNESS FOR MONETARY POLICY

Benjamin M. Friedman

Working Paper No. 3266

NATIONAL BUREAU OF ECONOMIC RESEARCH

1050 Massachusetts Avenue

Cambridge, MA 02138

February 1990

This paper is part of NBER's research program in Financial Markets and Monetary Economics. Any opinions expressed are those of the author and not those of the National Bureau of Economic Research. 
NBER Working Paper \#3266

February 1990

\section{IMPLICATIONS OF CORPORATE INDEBTEDNESS FOR MONETARY POLICY}

\section{ABSTRACI}

The extraordinary increase in reliance on debt by U.S. business in the 1980 s has generated widespread concern that overextended borrowers may become unable to meet their obligations and that proliferating defaults could then lead to some kind of rupture of the financial system, with ensuing consequences for the nonfinancial economy as well. The thesis advanced in this paper, however, is that the more likely threat posed by a continuing rapid rise of corporate indebtedness is instead a return to rapid price inflation. In particular, a review of recent developments lead to four specific conclusions:

First, problems of debt service within the private sector are more likely to arise among business borrowers, not households. Because businesses, and especially corporations, have used much of the proceeds of their borrowing merely to pay down their own or other firms' equity, their interest payments have risen to postwar record levels compared to either their earnings or their cash flows.

Second, despite these high debt service burdens, debt default on a scale large enough to threaten the financial system as a whole is unlikely in the absence of a general economic downturn. But the sharp increase in indebtedness has made U.S. businesses crucially dependent on continued strong earnings growth.

Third, the consequent need to prevent a serious recession - - so as to preclude the possibility of a systemic debt default -. will increasingly constrain the Federal Reserve System's conduct of monetary policy. The Federal Reserve's reluctance to risk a situation of spreading business (and LDC) debt defaults, especially with the U.S. commercial banking system in its current exposed position, will increasingly prevent it from either acquiescing in a recession or bringing one about on its own initiative.

Fourth, over time this constraint will severely limit the ability of monetary policy to contain or reduce price inflation. Episodes of disi in the United States since World War II have invariably involved busi. recessions, including declines in business earnings and increases in bankruptcies and defaults. If the economy's financial system has beco. fragile to withstand any but the shortest and shallowest recession, it is unlikely to be able to support a genuine attack on inflation by monetary policy.

Benjamin M. Friedman Department of Economics Harvard University Littauer Center 127 Cambridge, MA 02138 
The extraordinary increase in reliance on debt by U.S. business in the 1980 s has by now attracted substantial attention. It has also generated widespread concern. The heart of this concern is the fear that a large number of overextended corporate borrowers may become unable to meet their obligations and that proliferating defaults could then lead to some kind of rupture of the financial system, with ensuing consequences for the nonfinancial economy as we11. In light of the level to which corporate debt service burdens have risen compared to corporate earnings and cash flows, together with the highly exposed position of the nation's largest commercial banks - - including exposure not just to debt created in leveraged buy-outs but also to the debt of developing countries - - these concerns are probably worth taking seriously.

The thesis advanced in this paper, however, is that the more likely threat posed by a continuing rapid rise of corporate indebtedness is instead a return to rapid price inflation. The basis for this argument is the role of the Federal Reserve System.

There is, inevitably, a degree of tension between any central bank's responsibility to conduct monetary policy so as to promote price stability and its responsibility to act as a lender of last resort, should a debt default crisis become incipient. The recent increase in corporate indebtedness has exacerbated that tension in the United States. In the absence of a response by the Federal Reserve, the risk of a debt crisis, as suggested by much of the 
recent discussion, might be a plausible outcome under any of several sets of circumstances. But there is no reason to presume that the Federal Reserve would not respond to such a prospect, should those circumstances arise.

Indeed, the argument put forth here is not just that the U.S. central bank would act vigorously should a debt default crisis appear imminent, but that preventing a situation in which such action would be necessary will, if it has not begun to do so already, constrain the Federal Reserve's ability to conduct an anti-inflationary monetary policy. Given the importance of monetary policy in either tolerating or arresting prior episodes of accelerating price inflation, the more likely end result of a continuation of current trends in business borrowing is therefore higher inflation.

Section I provides a background for this discussion by briefly reviewing the record of inflation and disinflation in the United States since World War II, including in particular the effects exerted on nonfinancial economic activity by disinflationary monetary policy Section II lays out the dimensions of the increased reliance on debt by U.S. business corporations and other private sector borrowers in the 1980s. Section III evaluates the extent to which this increased corporate indebtedness has increased the economy's financial fragility. Section IV explores the resulting implications for the conduct of monetary policy. Section $V$ summarizes the paper's principal conclusions. 


\section{Price Inflation, Monetary Policy, and Economic Activity}

No subject has more thoroughly dominated the discussion of monetary policy, especially since World War II, than the twin questions of how policy can best promote price stability and what consequences for nonfinancial economic activity follow from doing so. Early in the postwar period it became apparent that fears of "secular stagnation" after the war's end had been exaggerated, and that the U.S. economy was not only advancing vigorously but so much so as to raise the prospect of an ongoing price inflation. At the same time, a growing understanding of the role monetary policy had played -- or failed to play -- in the disasters of the 1930 s heightened awareness of the power of monetary policy to affect real economic activity, for better or worse. The resulting tension has pervaded the discussion, and presumably the actual conduct, of monetary policy ever since.

Through much of the postwar period, the prevailing view was that monetary policy influenced price inflation primarily, if not only, by affecting nonfinancial economic activity. "Keynesian" theory summarized the underlying dependence of inflation on the economy's utilization of its real resources first in the simple Phillips curve, and later in the "expectations-augmented" elaboration of the same idea. ${ }^{1}$ Both variants made explicit the connection running from monetary policy to real economic activity to wage and price setting behavior. The "monetarist" alternative, couched primarily in terns of nominal magnitudes, was necessarily somewhat more vague about these connections at the theoretical level. But both Friedman and Schwartz (1963) and the flood of empirical studies that their work inspired typically showed a substantial (albeit temporary) effect of monetary policy on real economic activity before the associated effect on inflation appeared. 
By the late 1970 s this line of thinking had even achieved something of a consensus on the quantitative magnitude of the short-run trade-off involved. When Okun (1978) surveyed a variety of econometric estimates of the costs of inflation reduction -- costs in terms of foregone employment, incomes, capital formation, and so on - - the answer he found was that each percentage point reduction in inflation achieved by monetary policy would require between two and six "point-years" of unemployment, with a median estimate of three point-years. $^{2}$ Such an unfavorable trade-off - - at the median, fifteen point-years of unemployment to cut the inflation rate by five percentage points - constituted a clear discouragement to an actively disinflationary policy.

By contrast, a radically different view of the way in which monetary policy affects the economy, developed during the 1970s, maintained that central bank actions that are anticipated in advance affect price and wage setting directly, with little or no consequence for real economic activity. ${ }^{3}$ According to this idea, disinflation is costless as long as the public receives warning of the central bank's actions, as summarized in the growth of some appropriate measure of the money stock. By announcing its money growth target in advance, and then ensuring that actual money growth followed the target closely, the central bank could achieve any desired reduction in inflation without consequence, adverse or otherwise, to the real economy. It is difficult to judge the exact extent of adherence to this alternative perspective by the outset of the $1980 \mathrm{~s}$, or the extent to which it influenced actual monetary policy decisions, but neither appears to have been negligible.

In the wake of the experience of recession and disinflation in the early 1980s, however, prevailing opinion has more nearly returned to the view that monetary policy in practice does affect price inflation mostly (if not only) by affecting real economic activity - - and, moreover, that the magnitudes involved 
in these relationships are about what they previously appeared to be. U.S. price inflation, as measured by the growth of the implicit deflator for gross national product, averaged 9.28 per annum during 1979-81, with a post-1947 peak of 9.78 in 1981. By 1982 inflation had slowed to 6.48 , and by 1983 it was down to 3.98 . It remained below 48 until 1989. The average inflation rate during 1986-88 was 3.18 per annum, fully six percentage points below the average in 1979-81. Especially by the standards of the U.S. experience since World War II, disinflation of this magnitude was impressive to say the least.

But behind this dramatic slowing of inflation was a period of tight monetary policy and with it a pair of business recessions, including the most severe downturn since the 1930s. Interest rates rose to postwar record levels first in 1980 , and then again in 1981, on either a nominal or a real basis. Unemployment, which had averaged $6 \%$ of the labor force during 1978-79, reached nearly 11 by the time the $1981-82$ recession ended. Utilization of industrial capacity similarly fell to a postwar record low. By the end of 1988 , the cumulative unemployment in excess of $6 \%$-- that is, the number of point-years of unemployment, based on a 68 "full employment" benchmark -- totaled $15 \%$. Compared to the six percentage point decline in the inflation rate, this experience therefore represented an overall trade-off of about two-and-a-half to one, just slightly better than Okun's median estimate. On the alternative assumption that the "full employment" unemployment rate was 68 in 1981 but declined to 58 by 1986, the cumulative excess unemployment during 1981-88 totaled 228. 'In that case the overall trade-off was about three-and-a-half to one, or just slightly worse than Okun's median estimate. 4

Regardless of whether the net result of the 1980 s disinflation was a little better or a little worse than the prior consensus estimate, the main point is that in the $1980 \mathrm{~s}$, as earlier on throughout the postwar period, using 
monetary policy to slow price inflation entailed substantial real costs.

Figure 1 sumarizes the U.S. experience in this regard since World war II by plotting the inflation rate (here measured by the consumer price index compared to four quarters earlier) together with the unemployment rate, for quarterly data spanning 1952-88. The disinflations of 1953-54, 1958-59, 1970-72, 1974-76 and, of course, $1981-83$ al1 stand out clearly in these data. So do the increases in unemployment in each of these episodes. Expect for two small and short-lived dips, one in 1967 and one in 1986, every reduction in inflation during this period of nearly four decades was accompanied by an increase in unemployment.

From the perspective of the problems posed for monetary policy by increasing business indebtedness, however, what matters about these episodes of disinflation is not unemployment per se, or even the associated loss of incomes and output, but the parallel effects on borrowers' ability to meet their obligations. Disinflationary monetary policy normally affects that ability in two ways. First, to the extent that borrowers' debt is short-term, or long-term but subject to a floating interest rate, tight monetary policy raises nominal interest rates and thereby increases the volume of debt service payments to be made. Second, declining output levels in most cases mean reductions in the earnings and cash flows that borrowers have available to meet those payments.

Figure 2 indicates the effect of tight money on business borrowers' debt service obligations by plotting the interest rate on prime 4-6 month commercial paper (quarterly data) together with the percentage growth in total interest payments made by all U.S. corporations engaged in nonfinancial lines of business (annual data), again for 1952-88. Comparison of figures 1 and 2 immediately shows that an increase in nominal interest rates preceded each of 


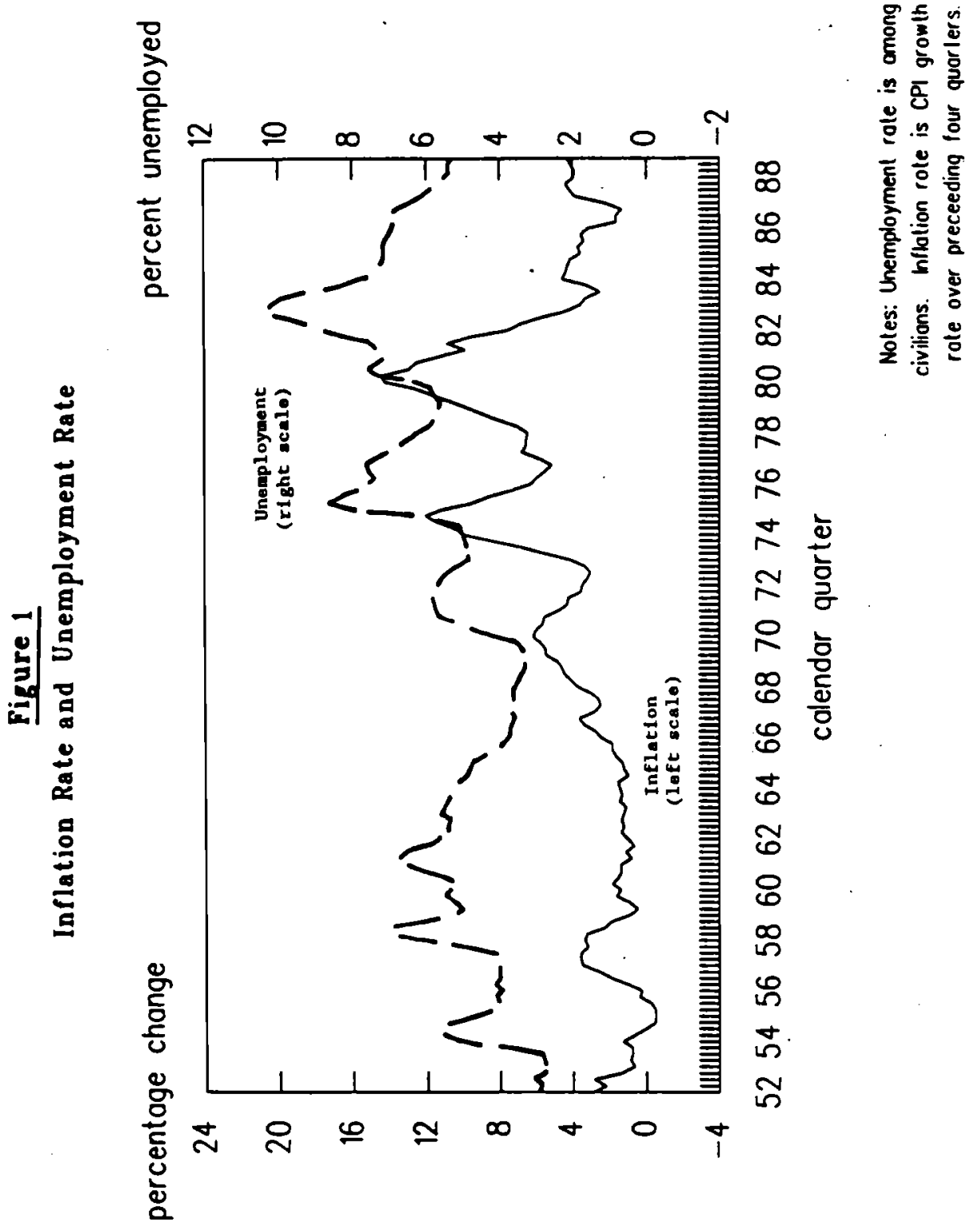




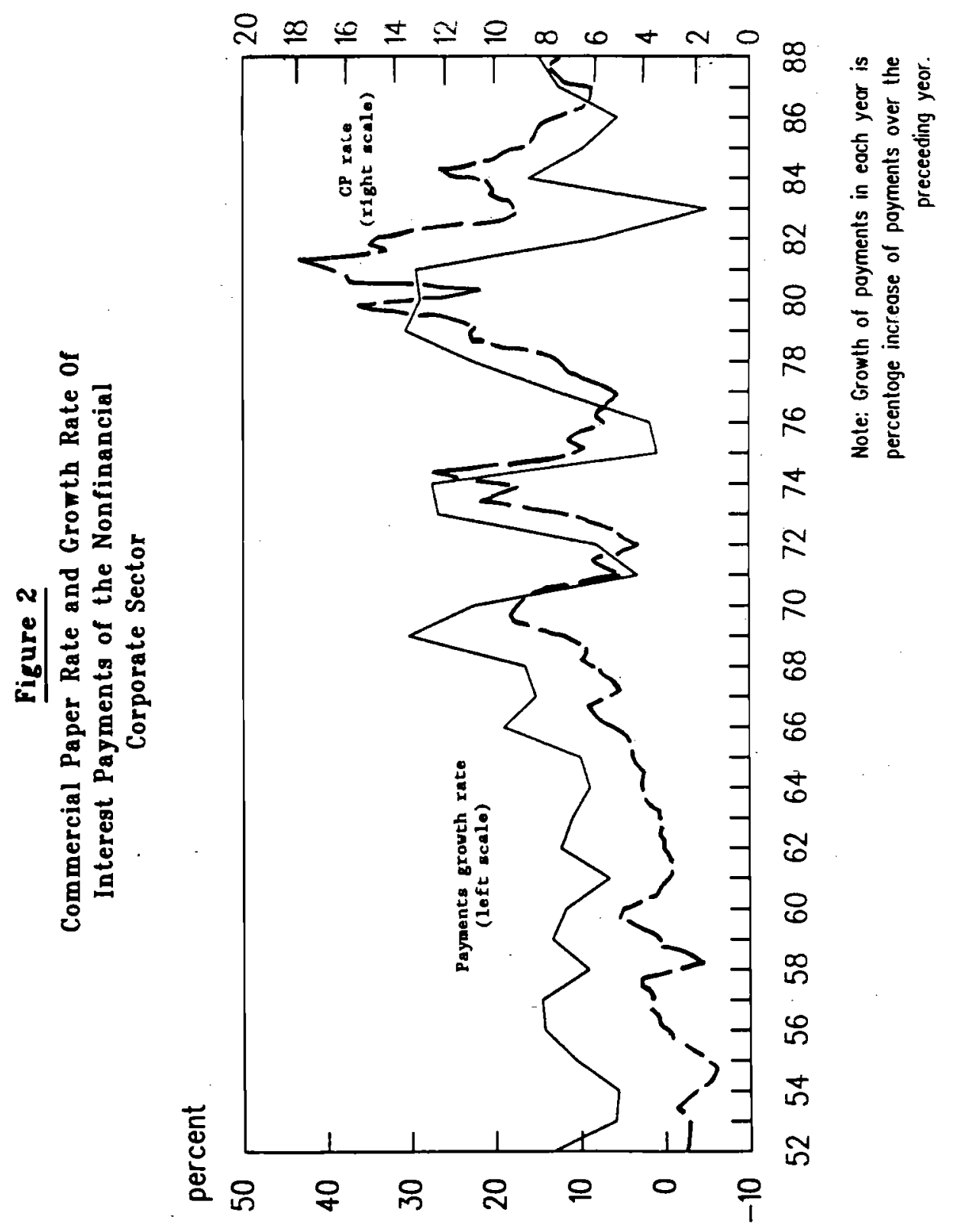


the recession-disinflation episodes that took place during this period. 5 Comparison of the two series plotted within Figure 2 further shows that, when nominal interest rates rise sharply, so do corporations' interest payments.

Figure 3 shows, not surprisingly, that episodes of recession and disinflation also typically have powerful effects on corporations' earnings -. here measured before both interest and taxes. Because the decline in earnings usually occurs well into a recession, by which time interest rates and therefore interest payments have peaked (see again Figure 2), the ratio of interest payments to earnings experiences much less cyclicality than does either series individually. Nevertheless, a sustained period of high interest rates, continuing on into the period in which business activity was slowing and earnings declining, would clearly raise debt service ratios. If there is concern about borrowers' potential bankruptcy and default prospects, therefore, these interactions provide not only a further reason for the central bank to want to keep recessions short but also a reason to cut interest rates promptly once a recession has begun. As is clear in retrospect from the record of inflation plotted in Figure 1, however, short, limited recessions are sufficient to arrest inflation for brief periods of time, but the effect is not necessarily lasting.

These respective movements of interest payments and earnings over the course of the typical business cycle show that disinflationary monetary policy can and does affect borrowers' ability to meet their obligations. But whether that effect is a major concern constraining the central bank's use of monetary policy to bring inflation down, or at least to keep it from increasing when the economy experiences adverse shocks (like an increase in oil prices), depends on more than just relationships among percentage changes in interest payments and earnings. The ultimate importance of these changes hinges on whether, even 


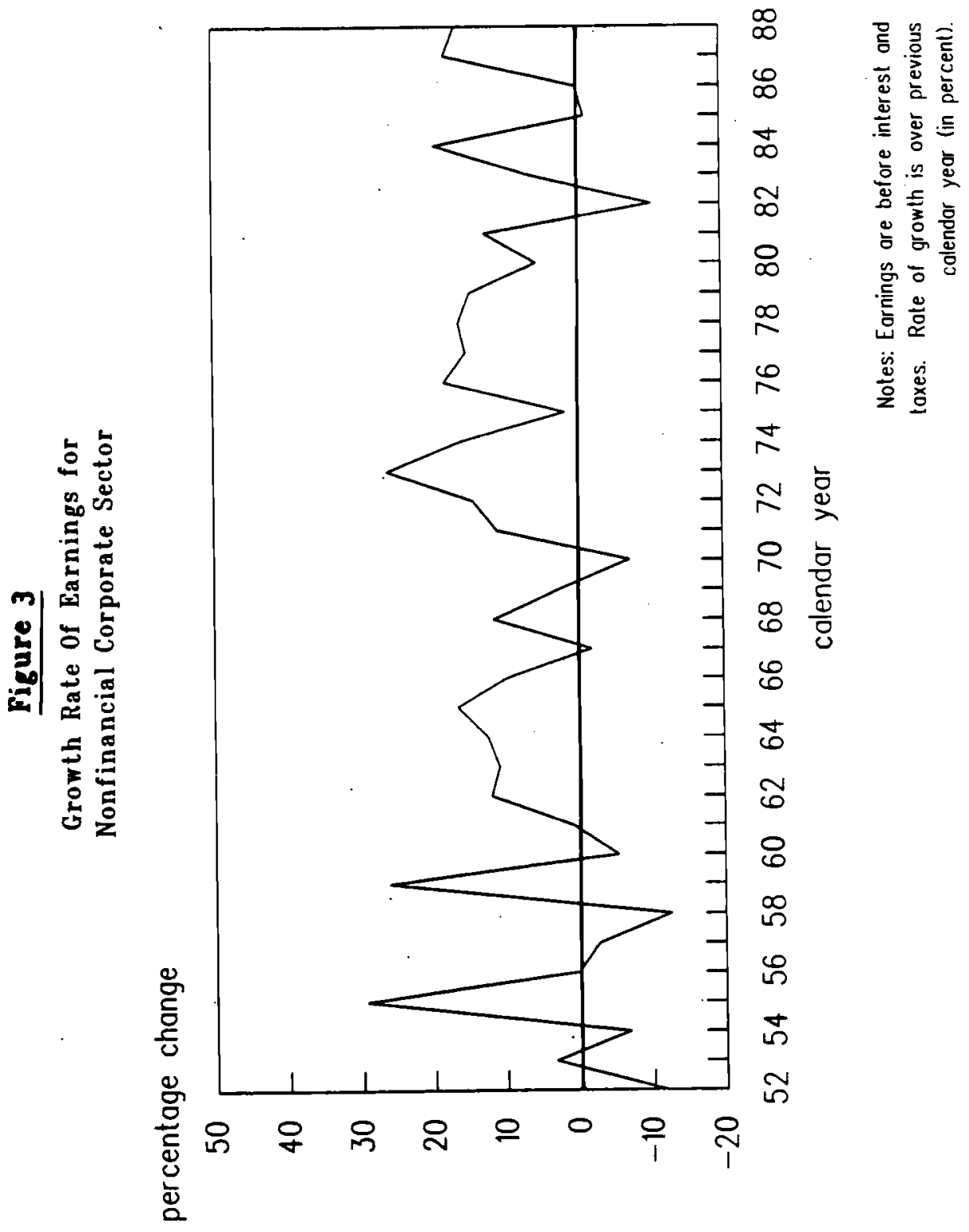


$-8-$

before the onset of tight monetary policy, interest obligations already bulk large against borrowers' ability to pay. And that, in turn, depends on how much they have borrowed and on the use they have made of the proceeds. 
II. Business Borrowing in the $1980 \mathrm{~s}^{6}$

Few developments in the U.S. economy in the 1980 s attracted so much attention as the extraordinary series of mergers, acquisitions, leveraged buy-outs and stock repurchases that have involved one major corporation after another. This attention is readily understandable, in that so many of the companies involved have been household names -- Nabisco, Gulf Oil, RCA, Phillip Morris, and United Airlines, among others -- and also because of the inherent fascination attached to transactions as large as $\$ 25$ billion (one-half percent of the nation's entire annual gross national product) for a single company. A whole new cadre of individuals has not only amassed astonishing personal wealth, seemingly overnight, but also come to represent high-visibility heroes or villains in the eyes of a large public that otherwise never displays the slightest interest in financial matters.

In fact, U.S. businesses are hardly alone in having borrowed in record volume in the 1980s. As Table 1 shows, since 1980 all major sectors of the U.S. economy except farms have increased their outstanding indebtedness at a pace significantly faster than the economy's overall growth. The huge budget deficits that became the hallmark of U.S. fiscal policy under the Reagan administration led to the first sustained peacetime increase in the federal government's debt, compared to national income, since the founding of the Republic. Households -- mostly individuals, but also including personal trusts and non-profit organizations -- have likewise borrowed record amounts. State and local governments have also increased their combined indebtedness, relative to national income, although their borrowing has clearly slowed since 1985 (presumably because of new tax legislation).

The across-the-board rise of debt relative to income that has occurred in this decade has marked a sharp departure from prior patterns of U.S. financial 


\section{TABLE 1}

Increase in the O.S. Debt Rat10, 1980-89

Debt Rat1o

\section{Borrover}

Households

Businesses

Corporations

Farms

Other

State-Local Governments

Federal Government

All Nonfinanctal Borrowers

\begin{tabular}{rrr}
\hline $1980: I V$ & & Change \\
50.28 & 62.38 & +12.1 \\
50.5 & 64.0 & +13.5 \\
29.1 & 37.6 & +8.5 \\
5.7 & 2.7 & -3.0 \\
15.7 & 23.7 & +8.0 \\
10.4 & 11.6 & +2.2 \\
26.1 & 42.2 & +16.1 \\
137.1 & 180.1 & +43.0
\end{tabular}

Notes: Figures for 1980:IV and 1989:I are quarter-end totals of credtt market liabilities, expressed as percentages of corresponding gross natlonal product (seasonally adjusted at annual rates).

Detall may not add to totals due to rounding.

Source: Board of Governors of the Federal Reserve System. 
behavior. Indeed, one of the most striking features of the U.S. financial system from the end of World War II until the 1980 s was the stable relationship between debt and economic activity. During this period the outstanding debt of all U.S. obligors other than financial intermediaries fluctuated within a narrow range, with no evident trend either up or down. As Figure 4 shows, the overall debt-to-income ratio was especially stable from the end of the Korean War until the 1980s, averaging $\$ 135.70$ of debt for every $\$ 100$ of gross national product during 1953-80, with standard deviation (based on annual data) of just $\$ 2.90$. At yearend 1980 , the total debt outstanding amounted to $\$ 137.10$ for every $\$ 100$ of gross national product, virtually unchanged. By March 31, 1989, however, the corresponding level was $\$ 180.10$, greater than any prior U.S. debt level recorded in this century except for 1932-35 (when many recorded debts had defaulted de facto anyway).

Roughly one-third of this increase is due to the mounting indebtedness of the federal government. This phenomenon has attracted widespread discussion, and rightly so -- not because the U.S. government is likely to default on its debt, but because the unending stream of outsized federal budget deficits behind it, the absence of either war or depression notwithstanding, absorbed approximately three-fourths of all net saving done in the 1980 s by U.S. individuals and businesses combined. As a result, the decade's net investment in business plant and equipment represented a smaller share of national income than in the 1950s, or the 1960s, or the 1970s. In addition, the link running from budget deficits to interest rates to exchange rates caused the dollar to be substantially overvalued for most of the 1980s, thereby severely impairing U.S. international competitiveness and, along the way, transforming the United States from the world's foremost lending country to its biggest borrower. 7 


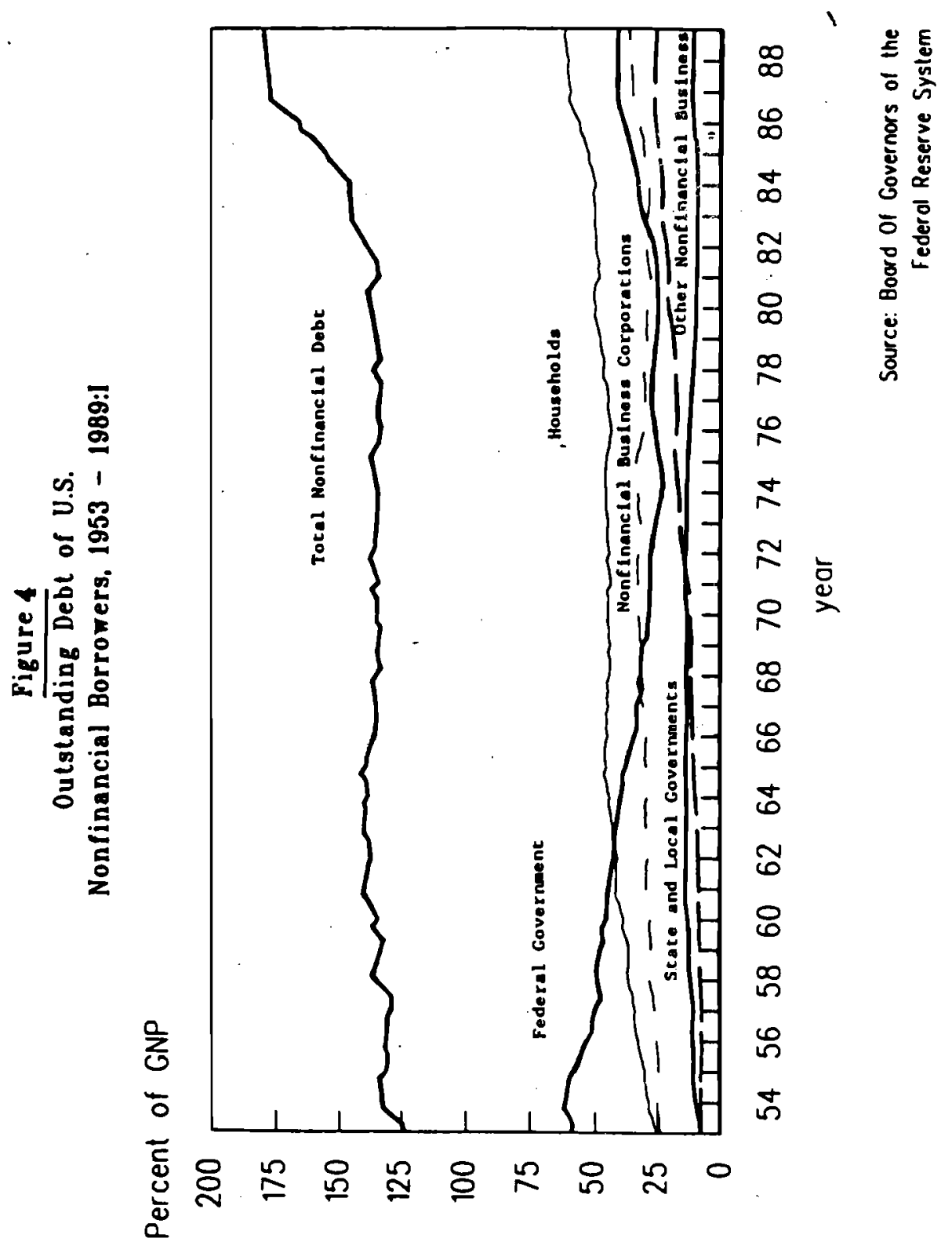


Private-sector borrowers, including both individuals and businesses, have accounted for the other two-thirds of the increase in total debt outstanding compared to the size of the economy. At least until the latest wave of corporate take-overs, popular discussion of this phenomenon devoted more attention to consumer debt, exploiting the myth of the "me generation" to highlight (and often exaggerate) how much individuals have borrowed. But while it is true that both households and businesses borrowed in record volume during the 1980s, on the whole they did so for different purposes. Because of this systematic difference in use of proceeds, it is instead business borrowing that constitutes the greater threat in terms of likely financial fragility.

Table 2 shows the aggregate balance sheet of U.S, households, according to broad categories of assets and liabilities, for yearend 1988 and decade-end dates back to 1960, with values for each date expressed as percentages of that year's gross national product. ${ }^{8}$ Households in the 1980 s clearly built up record debt levels, but at the same time they built up record asset levels, including not just equities and other assets exhibiting high price volatility, but also liquid assets and other stable-price debt instruments. As a result, aggregate-level household net worth has shown no significant deterioration relative to the size of the economy during this decade, and that remains true after the October 1987 stock market collapse.

By contrast, during the 1980 s U.S. corporations engaged in nonfinancial lines of business increasingly borrowed not to invest, in either tangible or financial assets, but to finance transactions in which they have paid down their own or other firms' equity. As a result, the corporate sector's aggregate net worth has declined substantially compared to gross national product. As Table 3 shows, as of yearend 1988 the corporate sector's holdings 
TABLE 2

Balance Sheet of U.S. Household Sector, 1960-88

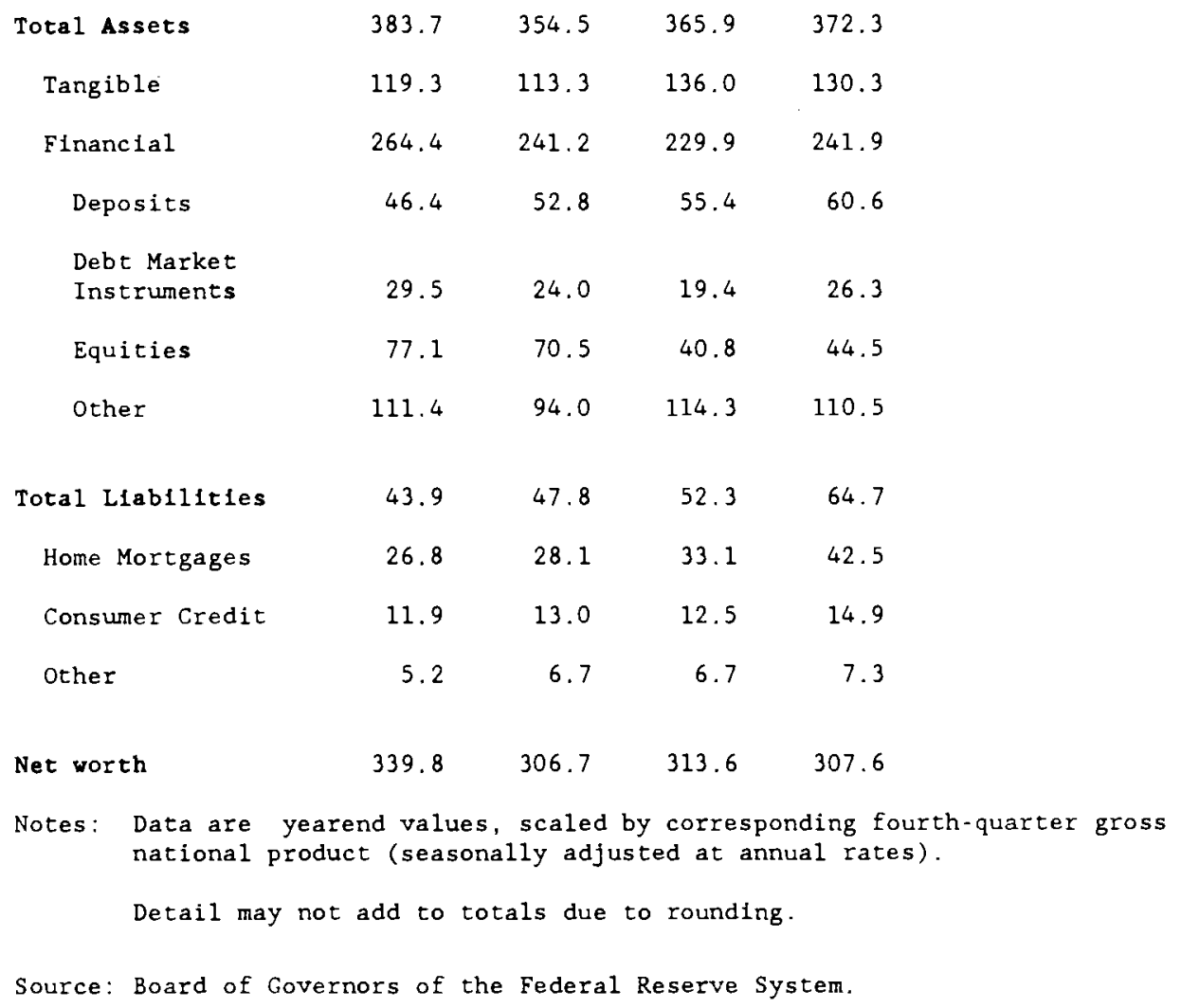

$\frac{1965}{8} \quad \frac{1970}{8} \quad \frac{1980}{8} \quad \frac{1988}{8}$ 


\section{TABLE 3}

Balance Sheet of U.S. Nonfarm Corporate Business Sector, 1960-88

\begin{tabular}{|c|c|c|c|c|}
\hline & 1960 & 1970 & 1980 & 1988 \\
\hline & $q$ & 8 & $q$ & \& \\
\hline Total assets & 131.5 & 126.6 & 140.5 & 128.0 \\
\hline Tangible & 96.1 & 90.7 & 104.9 & 92.9 \\
\hline Financial & 35.4 & 35.9 & 35.6 & 35.1 \\
\hline Iiquid & 10.0 & 6.7 & 6.9 & 10.1 \\
\hline other & 25.4 & 29.2 & 28.7 & 25.0 \\
\hline Total liabilities & 46.4 & 52.1 & 45.1 & 53.7 \\
\hline Market debt & 30.0 & 34.2 & 29.1 & 37.4 \\
\hline Trade debt & 12.4 & 15.5 & 12.2 & 10.2 \\
\hline other & 4.0 & 2.4 & 3.8 & 6.2 \\
\hline Net worth & 85.2 & 74.5 & 95.4 & 74.3 \\
\hline
\end{tabular}

Notes: Data are yearend values, scaled by corresponding fourth-quarter gross national product (seasonally adjusted at annual rates).

Data for trade debt reflect a series break at 1974.

Detail may not add to totals due to rounding.

Source: Board of Governors of the Federal Reserve System 
of financial assets stood in roughly the same relation to gross national product as in 1980, but holdings of tangible assets, like plant and equipment, had declined -. the consequence of nearly a decade of fiscal policies that systematically impeded business capital formation. At the same time, the corporate sector's outstanding debt had risen sharply from the fairly stable trend that prevailed until 1980. (The recorded decline between 1970 and 1980 in corporate debt compared to gross national product mostly reflects a statistical discontinuity in the data for trade debt.) With assets down but debt up, corporate net worth has fallen substantially compared to the size of the economy. By yearend 1988 this decline had returned the corporate sector's net worth to the same level compared to gross national product that prevailed in 1970, despite the fact that 1988 was the sixth year of a sustained economic expansion while in 1969 and 1970 the economy was in recession.

Table 4 shows the analogous but even more severe (in percentage terms) balance sheet deterioration among nonfarm noncorporate businesses. In contrast to corporations, unincorporated firms in the 1980 s did, on average, modestly increase their holdings of financial (thought not tangible) assets compared to the size of the economy. Because they increased their outstanding debt so much faster, however, the noncorporate sector's net worth has also declined in relative terms.

Just why all this has happened is not clear. To be sure, there is no lack of ready explanations for U.S. businesses' eagerness to take on debt. The U.S. tax code penalizes equity finance, and correspondingly favors reliance on debt, by treating interest payments as a cost of doing business and therefore allowing borrowers to deduct them from taxable income. At the same time, interest and dividends are treated alike in the taxation of income earned by most recipients. Hence the total tax imposed on distributions of business 
TABLE 4

Balance Sheet of U.S. Non-Farm Non-Corporate Sector, 1960-88

\begin{tabular}{|c|c|c|c|c|}
\hline & 1960 & 1970 & 1980 & 1988 \\
\hline & 8 & 8 & 8 & 8 \\
\hline Total Assets & 52.3 & 43.6 & 60.9 & 63.6 \\
\hline Tangible & 47.0 & 40.5 & 55.7 & 55.2 \\
\hline Financial & 5.3 & 3.2 & 5.2 & 8.4 \\
\hline Liquid & 2.4 & 1.4 & 2.0 & 3.8 \\
\hline Other & 2.9 & 1.7 & 3.2 & 4.7 \\
\hline Total Liabilities & 7.5 & 10.3 & 18.2 & 27.6 \\
\hline Marketable Debt & 5.3 & 9.8 & 15.7 & 23.8 \\
\hline Trade Debt & 2.2 & 0.5 & 1.3 & 1.3 \\
\hline other & 0.0 & 0.0 & 1.2 & 2.5 \\
\hline Net worth & 44.8 & 36.4 & 42.7 & 35.6 \\
\hline
\end{tabular}

Notes: Data are yearend values, scaled by corresponding fourth-quarter gross natioanl product (seasonally adjusted at annual rates).

Detail may not add to totals due to rounding.

Source: Board of Governors of the Federal Reserve System. 
earnings depends crucially on the debt-equity mix of the firm's capital structure. This discrimination is all the greater in that borrowers can deduct the full (nominal) interest that they pay, including not just that part corresponding to the "real" interest rate but also the part that compensates the lender for the erosion of principal value due to inflation. In an economic sense, therefore, borrowers can and do deduct a part of what amounts to repayment of debt principal.

In addition to the nonneutrality of the tax code, other features of the U.S. Financial system also favor reliance on debt. Legal and regulatory restrictions on ownership of equities by different kinds of financial intermediaries create an incentive to fashion instruments (like "junk bonds") that have risk and return properties sinilar to equities but nonetheless constitute debt in the eyes of the relevant authorities. Larger underwriting spreads for equity offerings than for debt offerings further increase the incentive to rely on debt when firms seek new capital. The greater speed at which firms can raise new debt than new equity is also important in contexts like unsolicited take-overs, in which timing can be all-important. And at a more fundamental level, Jensen has argued that high debt levels serve the useful function of making firms' intentions to pay out cash flow credible, and thereby helping to resolve potential "agency" conflicts between managements and their shareholders. ${ }^{9}$

What remains a puzzle, however, is why the explosion of business debt is occurring now. Each of these features of the U.S. financial system that creates a basic tendency toward debt financing has been present for a long time, and some are less potent now than they were in the past. The reduction in tax rates in the $1980 \mathrm{~s}$, for example, should have reduced the incentive to borrow. So should the slowing of inflation. Yet the use of debt by U.S. 
businesses has clearly increased. Although corporations' cash flows have increased rapidly during the 1980 s, so that Jensen's explanation appears to have merit at the aggregate leve1, Blair and Litan (1989) have shown that the industry-level evidence contradicts it. Specifically, those industries that have experienced the greatest increase in cash flows are not the ones that have increased their indebtedness the most. At least for the present, the most honest answer to the question of why all this happened in the 1980 s is that nobody really knows.

Regardless of why it is happening, however, the massive substitution of debt for equity capitalization that took place in the 1980 s has caused business interest obligations to rise sharply as a share of earnings. Figure 5 documents this increased interest drain at the aggregate level by showing the ratio of interest payments to available earnings before interest and taxes, since the end of World War II, for corporate and noncorporate firms within the U.S. nonfinancial business sector. For purposes of comparison, the figure also shows the ratio of personal interest payments to pre-tax personal income. Specially for the corporate sector, the deterioration of interest coverage since 1980 has been dramatic. On average during the 1950 s and 1960 s, it took 16 cents of every dollar of pre-tax (and pre-interest) earnings to pay corporations' interest bills. The corresponding average for the 1970 s was 33 cents. Since 1980 it has been 56 cents. In no year since 1981 has the interest share of earnings been below 50 cents on the dollar.

Indeed, the corporate sector's experience in this regard during the $1980 \mathrm{~s}$ vividly demonstrates the impact of continued massive borrowing for purposes of equity substitution rather than asset creation. In 1982, in the midst of the most severe business downturn since the 1930s, aggregate pre-tax corporate earnings (before interest payments) were depressed by 11 f from year-earlier 


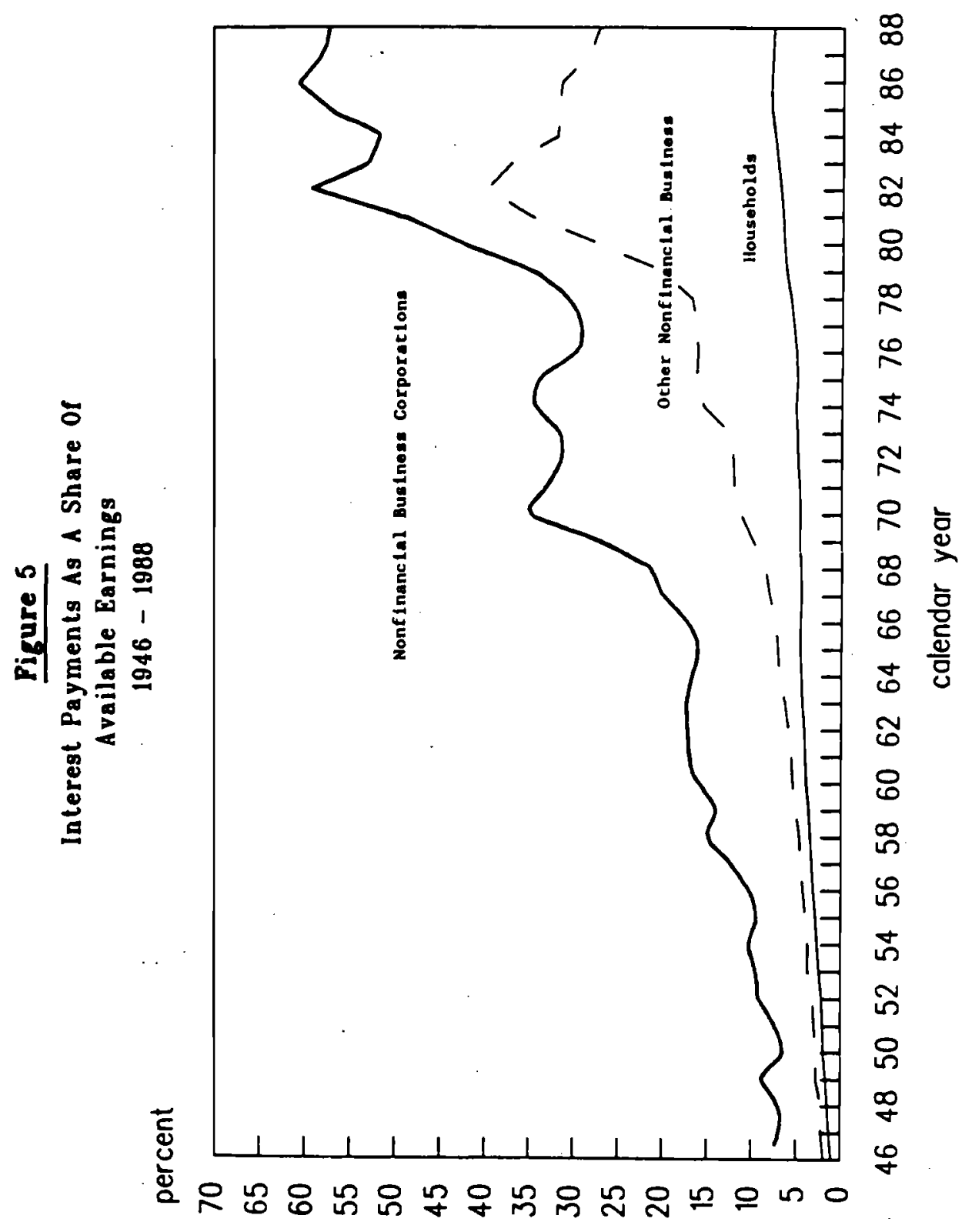


levels, and the interest rate on short-term business borrowing reached a record 16.668 (in May). Not surprisingly, the share of corporations' earnings required to meet their interest bills also rose to a record level, 59 cents out of every dollar. By 1986 earnings had rebounded by $25 \%$, and the average short-term borrowing rate was down to $6.39 \%$. But by then corporations had taken on so much additional debt that in 1986 interest payments were up to 60 cents of every dollar of earnings, yet another new record. By 1988 earnings had risen still further, to $37 \%$ above ever the 1986 level, and the average short-term borrowing rate was $7.68 \%$. But with the further borrowing that had taken place, interest payments still stood at 58 cents of every dollar of earnings.

The experience of unincorporated businesses in this regard resembled that of corporations until the 1980s, but since then it has differed sharply. Mirroring the corporate sector's interest-to-earnings ratio, the noncorporate sector's interest payments rose from only 6 cents of every dollar of pre-tax (and pre-interest) earnings on average in the 1950 s and 1960 s to 17 cents on average in the $1970 \mathrm{~s}$, and 33 cents in the $1980 \mathrm{~s}$. But after peaking at 40 cents on the dollar in 1982 -- to recall, during the recession - interest payments as a share of earnings dropped to only 27 cents on the dollar by 1988 .

In contrast to the case of either corporations or unincorporated businesses, the trend of household sector interest payments in the 1980 s showed no noticeable break with prior experience. Personal interest payments averaged 4 cents of every dollar of pre-tax (and pre-interest) personal income in the $1950 \mathrm{~s}$ and 1960s, and 5 cents in the 1970s. Since 1980 the average has been 7 cents. As of 1988 the ratio had been essentially unchanged for half a decade, with the value for every year during 1984-88 falling within the narrow range of $7.6-8.0$ cents on the dollar. 
Figure 6 presents an alternative perspective on business borrowers' ability to meet their current obligations by showing, again separately for the corporate and noncorporate sectors, the ratio of interest payments to cash flow including earnings (as in Figure 5) plus depreciation. Interest payments look smaller compared to this expanded measure of ability to pay, especially for corporate borrowers, but the overall trends are mostly unchanged from those shown in Figure 5. The corporate sector's ratio of interest payments to cash flow also rose dramatically during the late 1970 s and the back-to-back recessions of 1980 and 1981-82, and, despite the strong recovery of cash flows and the general fall in interest rates, as of 1988 it had shown no improvement whatever from the bottom of the last recession. The improvement since 1982 in unincorporated businesses' interest-to-cash flow ratio is much less impressive than the parallel improvement in that sector's interest-to-earnings ratio shown in Figure 5 .

Especially before the October 1987 stock market crash, a familiar answer to all this was that debt levels and interest burdens were high compared to current earnings, but not in relation to the earnings that U.S. business was likely to enjoy in the not-very-distant future: that the U.S. economy had entered a new era of stability and rapid growth, which soon enough would deliver the higher earnings needed to service the debts of all but the usual small percentage of corporations that are obviously mismanaged or extraordinarily unfortunate. The natural evidence to which to point in support of this optimistic view was the high and rising level of stock prices, which provided at least one plausible estimate - - some would say the best available estimate - of what those future earnings would be. 


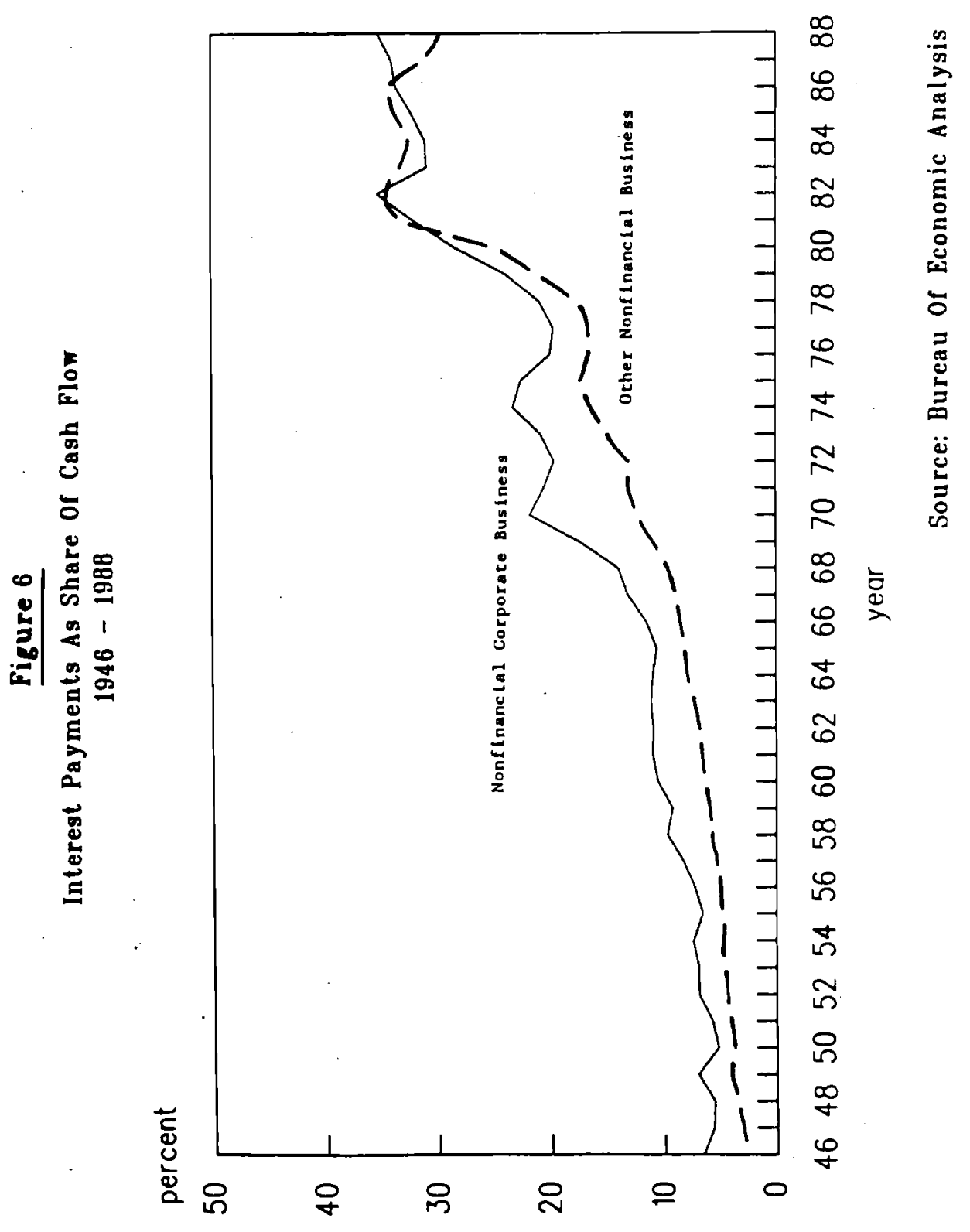


The crash substantially changed all that, and the situation is no longer the same even though, as of the time of writing, stock prices have approximately regained their pre-crash highs. Figure 7 plots the ratio of the book value of debt to the market value of equity for the aggregate of U.S. nonfarm nonfinancial business corporations, for yearend values since World War II and three other selected dates: August 25, 1987 (the stock market peak), October 19, 1987 (the market crash), and September 9, 1989.10 The results of this calculation shed little new light on the issue at hand, however. As of September 1989, the corporate sector's market-value leverage remained well below the post-war record level (above 1.0) set in 1974, when firms borrowed heavily and then the stock market crashed. But it likewise remained substantially above the average level that prevailed before then. Viewed from another perspective, aggregate corporate leverage in September 1989 stood about where it did at yearend 1980, or at the end of the 1981-82 recession, despite that fact that by September 1989 stock prices had fully regained the record level previously reached in August 1987.

Finally, it is also always possible that the impression given by any of the sector-aggregate data examined above may not correspond to the reality of borrowing and asset accumulation by individual firms and families. The fact that the household sector as a whole has accumulated substantial assets to match its record issuance of debt in the 1980 s would be of limited help in the event of an economic downturn if the families who had bought the assets had little or no overlap with the families who had issued the debt. For analogous reasons, the fact that the corporate sector as a whole has borrowed far in excess of its creation of new assets in the 1980 s would not increase the economy's financial fragility if the firms that had done the borrowing were mostly ones that had only little debt, or excess liquidity, to begin with. 


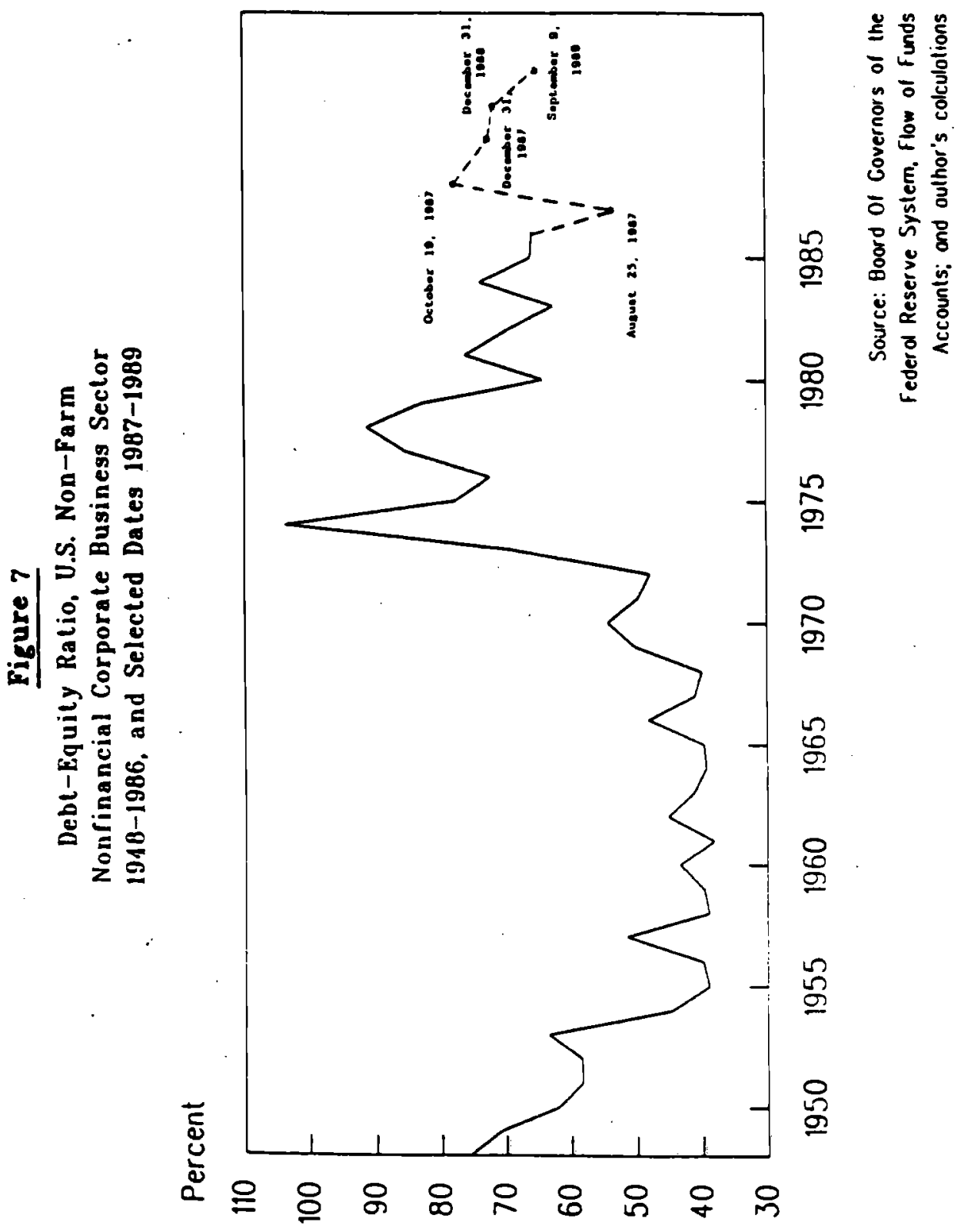


Investigating the possibility of such a divergence between the aggregate data and the disaggregated reality is difficult for the household sector because of the paucity of available information on individual families' holdings. 11 By contrast, disaggregated data on the corporate sector are readily available, at least for the larger firms.

Bernanke and Campbel1 (1988) have investigated this possibility using data from the Compustat files to study the detailed balance sheet and earnings record of some 1,400 U.S. corporations for years beginning in 1969 . On the whole, their findings from these disaggregated data reinforce rather than contradict the impressions drawn above on the basis of aggregate data. For the median firm in their sample, interest expense rose from 13 cents of every dollar of cash flow in 1969 to 22 cents in 1986. For firms in the 90th percentile for this ratio, however, interest expense rose from 34 cents of every dollar of earnings in 1969 to $\$ 1.65$ in 1986. (In other words, by 1986 more than one firm in ten was not earning its interest due). Nor did this sharp deterioration reflect merely the vagaries of one year's earnings. Compared to a trailing three-year average of earnings, interest expense for firms in the 90th percentile rose from 44 cents on the dollar of in 1971 to $\$ 1.02$ in 1986.

An exercise carried out by Bernanke and Campbell that is especially relevant to the focus of this paper was to "replay" the 1981-82 recession in the sense of considering the implications of the actual 1981-82 percentage decline in firms' earnings in the context of the typically higher debt levels taken on as of 1986 . The results indicated that, in the absence of some offsetting factor, default levels in such an event would have substantially exceeded those experienced during the 1981-82 recession itself. By the second year of the recession, for example, firms in the 90 th percentile of 
indebtedness would have had negative cash flow, and firms in the 75 th percentile would have had interest due equal to 45 cents of every dollar of cash flow.

These results are all the more striking in that Bernanke and Campbell's sample of firms apparently did much less borrowing than the average U.S. corporation, and likewise accounted for a disproportionately small share of equity repurchases. In 1986, for example, firms in their sample raised just $\$ 40$ billion from debt issues (net of repayments), verst:s $\$ 190$ billion for the nonfarm nonfinancial corporate business sector as a whole (as measured by the Flow-of-Funds Accounts). Similarly, firms in Bernanke and Campbell's sample repurchased only $\$ 7$ billion of equity in 1986 , versus $\$ 77$ billion for the nonfinancial corporate sector overall.

In sum, the erosion of corporate balance sheets and interest coverage that show up so strongly in sector-aggregate data for the 1980 s do appear to correspond to the reality of borrowing and asset accumulation (or lack thereof) by individual firms. 


\section{Bankruptcies and Defaults in the $1980 \mathrm{~s}$}

The mere fact that U.S. businesses have taken on higher levels of indebtedness in the 1980 s does not necessarily mean that a debt service problem, much less the threat of widespread default, is likely. As much of the recent discussion of these developments has emphasized, even today most U.S. corporations remain less highly leveraged than their European or Japanese counterparts. If businesses elsewhere can sustain much greater debt burdens, the reasoning goes, why cannot ours? Especially in light of the usual cost advantages of debt over equity capitalization, from one perspective U.S. firms are merely trying to eliminate a competitive disadvantage under which they have labored for years.

Simple comparisons between corporate capital structures in the United States and abroad are of limited value for these purposes, however, in that they fail to take into account differences in the institutional, legal, and philosophical environment that are potentially of great significance in this context. Foreign financial markets and financial institutions are typically structured very differently than those in the United States. The ownership of corporate debt and equity securities is typically more highly concentrated than here, and -. unlike in the United States, where there is no universal banking - major lenders are also often major equity holders in the businesses to which they lend. As a result, the entire relationship between the financial sector and nonfinancial industry has a sharply different character.

At the same time, foreign attitudes toward competition versus cooperation (or even cartelization) within industry have traditionally differed from those in the United States. So have attitudes toward the relationship between the private sector as a whole and the government, including in particular the willingness of both financial institutions and nonfinancial firms to accede to 
various forms of governmental guidance. In some cases, a close corollary of this willingness has been a different set of presumptions about the government's readiness to intervene, if necessary, to rescue distressed private firms.

No one knows just how important any or all of these differences have been in accounting for the historically higher leverage of European and Japanese corporations. Much systematic research needs to be done on such questions. The findings of that research may indicate, for example, that specific changes in U.S. legal and institutional structures would be useful, in that they would then permit U.S, corporations safely to adopt debt burdens more nearly comparable to those abroad. In the absence of such changes, however - - indeed, in the absence even of knowledge about just which differences between U.S. institutions and those abroad are most important in this regard. the simple fact that U.S. corporations' debt burdens have not yet risen as high as those of foreign firms is also not reassuring.

The actual experience of business bankruptcies and defaults in the $1980 \mathrm{~s}$ may therefore be a better guide to the implications of U.S. firms' new leverage levels. Table 5 presents data on the business bankruptcy rate (number of failures per 10,000 concerns) and the volume of liabilities in business failures (scaled in relation to gross national product) since the Korean War. For purposes of comparison, the table presents comparable data on consumer loan delinquencies (as a percentage of loans outstanding). As the summary of the pre-1980s experience in the upper half of the table indicates, all three measures of debtors' distress have fluctuated in a strongly cyclical fashion, typically rising during and immediately after recessions and then falling back to pre-recession levels after the first year or so of the subsequent expansion. Also, before the 1980s neither measure of business borrowers' 
TABLS 5

Debe Default in Post-Var Business Recessions

$\begin{array}{clc}\text { Huber of } & \text { Llabllities in } & \text { Delinquent Consumer } \\ \text { Business Pallures } & \text { Business Fellures } & \text { Installment Lons } \\ \text { (per } 10,000 \text { concerns) (percent of GNP) } & \text { (percent outstanding) }\end{array}$

Mean for 1953.80

44

.16

1.91

Recessions during 1953-80

$\begin{array}{llll}1954 & 42 & .12 & 1.89 \\ 1958 & 56 & .16 & 1.67 \\ 1961 & 64 & .20 & 1.78 \\ 1970 & 44 & .19 & 1.84 \\ 1975 & 43 & .27 & 2.61 \\ 1980 & 42 & .17 & 2.61\end{array}$

Experlence since 1980

1981

1982

1983

1984

1985

1986

1987

1988
61

88

110

116

113

112

88

88

.23
.49
.47
.46
.42
.44
.28
.31

2. 38

2. 24

2.01

1. 96

2. 31

2. 34

2. 41

2. 35

Notes: Delinquent consuner loans are loans in arrears nore than chlrey days.

Business fallures conprise concerns involved in court proceedings or voluntary ections involving loss to czeditors.

Liablifies in business fallures exclude long-term, publiely-held securteles.

Data for number of business fallures and liabllities in business failures are adjusted for serles breaks after 1983.

Figures for 1988 are based on preliainary data.

Sources: Anerican Bankers Assoctation, Dun \& Bradstreet, U.S. Dapartment of Comerce. 
distress showed any significant trend, although the consumer delinquency rate did rise to new highs in the 1970 s (no doubt at least partly because of new bankruptcy legislation).

By contrast, the experience of bankruptcy and default by U.S. businesses since 1980 has been beyond all prior experience since World War II, despite the sustained economic expansion that began in 1983. Not surprisingly, both the bankruptcy rate and the default rate rose to record levels in 1982. After all, the 1981-82 recession was, by most measures, the most severe of the postwar period. What has been surprising, however, is that both bankruptcies and defaults continued to rise for four years during the ensuing expansion, and even by 1988 both the bankruptcy rate and the default rate remained far above any previous postwar level. Moreover, the contrast between the respective experience of business borrowers and households in this regard is fully in line with what would be expected from the balance sheet and interest coverage comparisons drawn in Section II. The level of delinquencies on consumer loans has not been out of the ordinary, either during or following the 1981-82 recession.

The fact that not only the business failure rate but the default rate too has been extraordinary in the 1980 s is of particular significance. Popular discussion of the increase in business bankruptcies has sometimes suggested that this phenomenon is merely the reflection of an especially fertile climate for new business start-ups created by tax reduction and deregulation since 1980. Since new start-ups are much more likely to fail than going concerns, any period in which start-ups abound will also be a period in which failures abound. The higher failure rate in the $1980 \mathrm{~s}$, so the argument goes, is therefore a sign of success, not trouble. But if all that were true, the 
failure rate would be high but not the default rate. New start-ups typically do not have large amounts of liabilities.

Moreover, popular impressions notwithstanding, it is also not true that the pace of business start-ups was been unusually rapid in the 1980s. Indeed, the opposite is the case. On average from the 1950 s through the $1970 \mathrm{~s}$, the number of new businesses incorporated each year rose at 6.08 per annum. Between 1980 and 1988 the average rate of increase was just 3.28 per annum, barely half of the previous growth. ${ }^{12}$ (From the recession bottom in 1982 until 1988, the average rate of increase was also 3.2 per annum.)

Because of the highly visible role played by leveraged buy-outs in the increase in corporate indebtedness in this period, it is instructive to examine in particular the default experience of the high-yield unsecured debt ("junk bonds") typically issued in the course of such transactions. Jensen, for example, has argued that there are several reasons why the higher debt levels carried after corporate reorganizations of this kind are unlikely to lead to increased default rates. One is that both the change in corporate ownership form and the higher debt level itself create incentives for gains in operating efficiencies, and hence faster growth of earnings with which to service the high debt. A second reason is that when the debt holders' stake is far greater than the firm's liquidation value, there are new incentives to seek alternatives to traditional bankruptcy and default procedures in the event that the anticipated higher earnings do not materialize. Third, several innovations in corporate financing - - strip financing, interest rate caps, interest rate swaps, and so on - further reduce either borrowers' exposure to interest rate risk or lenders' incentives to put a borrower facing insufficiencies into bankruptcy. 13 
The actual experience of junk bond defaults has been subject to substantial debate. Most researchers have agreed that the overall default rate on such securities has been modest. ${ }^{14}$ By contrast, Asquith et al. (1989) have shown that this finding hinges on the great increase in the volume of such securities issued in recent years, together with the tendency for most defaults to occur only several years after the time of issue. Although the default rate for high-yield bonds that have been outstanding for several years or more is high, the "universe" of bonds outstanding at any point in time consists disproportionately of bonds issued only recently, and therefore exhibits only the familiar modest default rate overall.

Table 6, reproduced from Asquith et al., shows that the cumulative default rate, measured for bonds issued in each year rises from only $3-8$ after three years to 25-33z after ten years. Nevertheless, with $\$ 31$ billion of junk bonds issued in 1986 and $\$ 13$ billion per annum on average in 1984-85, versus only $\$ 1$ billion per annum on average during 1977-82, the overall default rate for all junk bonds issued during 1977-86 remains just $8 \% .15$ No doubt the patterns shown in Table 6 reflect not just the passage of time per se but also the fact that firms issuing bonds since 1983 have not had to face the burden of meeting debt service payments during a recession. At least until the next recession occurs, however, separating out these two factors is difficult if not impossible.

In the end, it is precisely that - the absence of a recession since 1982 - - that makes both the general business bankruptcy experience shown in Table 5 and the specific default experience on high-yield bonds shown in Table 6 so troubling. If the record of 1983-88 provides a reliable guide to U.S. business borrowers' ability to service their newly higher debt loads when the economy is continuously expanding, what will happen when - - or if - there is a significant recession? 


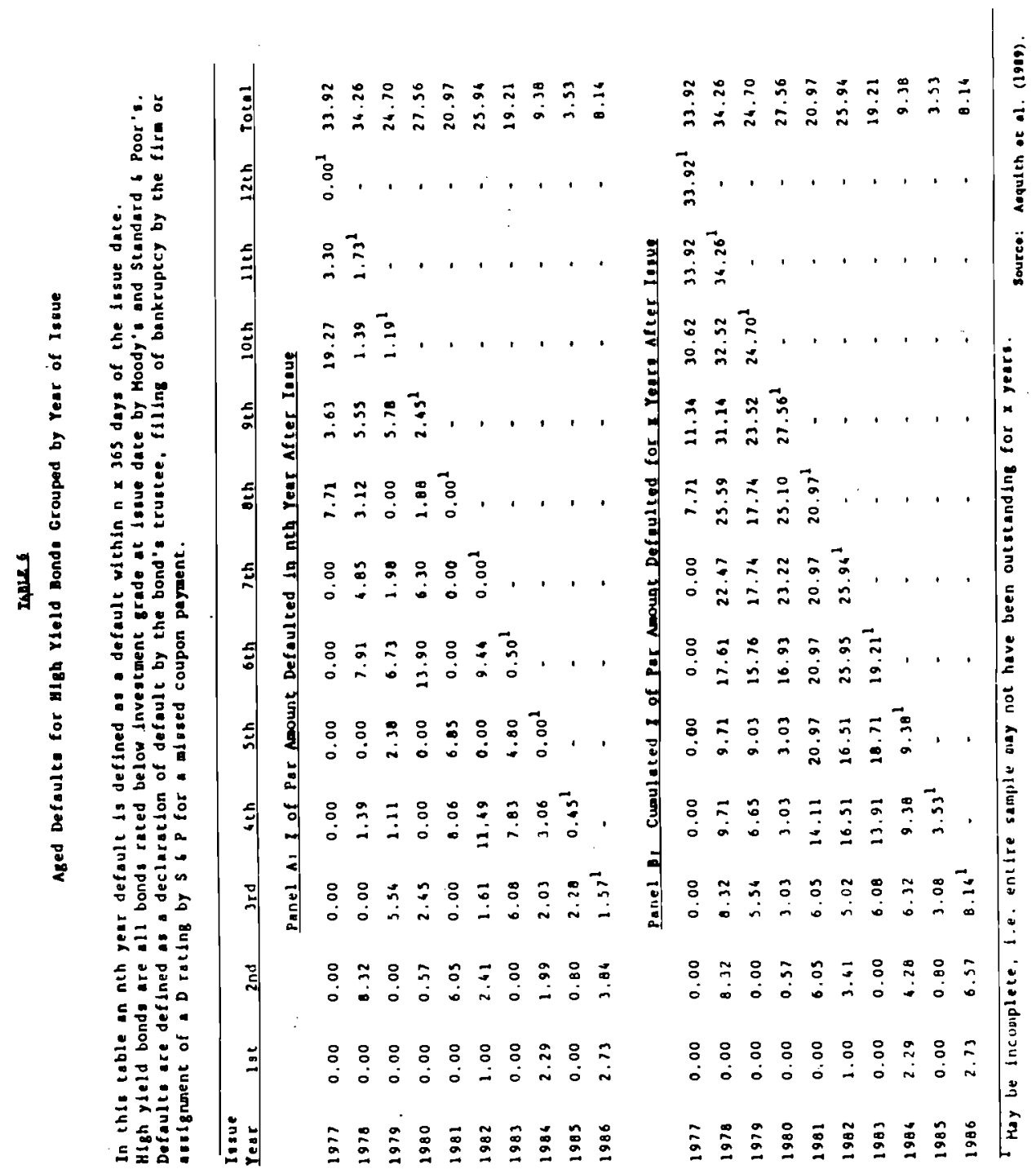




\section{Implications for Monetary Policy}

Central banks' traditional sensitivity to any threat of financial instability stems from the fundamental two-way interrelationship between the financial phenomenon of debtors' distress and contractions in nonfinancial economic activity. On one side, the chief economic danger posed by an overextended debt structure is that the failure of some borrowers to meet their obligations will lead to cash flow inadequacies for their creditors -- who may, in turn, also be borrowers, and so on -- and that both borrowers and creditors facing insufficient cash flows will then be forced to curtail their demands in the economy's product and factor markets. Similarly, forced disposal of assets by debtors and others facing insufficient cash flows will lead to declines in asset prices that erode the ability of other asset owners to realize the expected value of their assets if sale becomes necessary, and will therefore threaten the solvency (in a balance sheet sense) of still others.

This causal process, running from financial constraint to nonfinancial contraction, has long been familiar in the history of business downturns. 16 Financial crises of one sort or another have occurred just prior to, or at the inception of, each of the half dozen or so most severe recorded declines in U.S. economic activity, as well as quite a few of the smaller declines. A common feature of these episodes was the inability of borrowers either to meet their debt service payments out of current cash flows or to arrange refinancing. In addition, before the founding of the Federal Reserve System these crises sometimes involved suspension of convertibility of deposits into currency.

But at the same time, the likelihood that an aggregate-level problem of debtors' distress will arise in the first place is clearly not independent of what is happening in the nonfinancial economy. Apart from occasional instances 
of recklessness, incompetence, or fraud, most borrowers typically expect to be able to service their debts in a timely fashion. In other words, they expect that their available cash flows - . and, if necessary, the value of their salable assets - - will be sufficient to meet the requisite sequence of payments due. For most borrowers, however, including individuals as well as businesses, both the size of cash flows and the value of marketable assets depend to a great extent on prosperity or recession in the economy at large. In particular, business downturns typically shrink the cash flows of many borrowers, slow cash flow growth for most others, and in may cases also reduce the market values of equities, houses, and other assets. Especially when these developments occur after a period of speculative activity that has bid up asset prices and inflated debt levels, the result can be a financial crisis. 17

Hence problems of financial instability are most likely to erupt in the context of just the kind of nonfinancial economic difficulty that they tend to aggravate. Limitations on individuals' and businesses' activities arising from widespread financial distress restrict economywide demands for goods and services and for labor and capital inputs, and thereby depress overall economic activity. But as the record of bankruptcies and defaults shown in Table 5 demonstrates, a contraction of economic activity is the most likely initial cause of widespread debtors' distress in the first place.

Whatever threat to financial stability the post-1980 rise in U.S. businesses' reliance on debt presents, for any period into the future, is therefore fundamentally dependent on the performance of the nonfinancial economy during that period. For example, if the economy in the 1990 s were to achieve a decade of sustained rapid growth, with only minimal interruptions. then it is plausible that whatever debt service problems emerged would be localized within specific industries, like energy and agriculture in the 
mid 1980s, or within specific geographical regions especially dependent on those industries. In that case, there would be little reason to expect the kind of widespread borrowers' distress that would be likely to exert contractionary pressures on nonfinancial economic activity. With sustained rapid growth of earnings, most borrowers would realize cash flows (and market values of assets) adequate to meet their obligations. Indeed, a sufficient period of sustained rapid economic growth could readily shrink the private sector's debt ratios back to their prior postwar ranges, not by reducing the numerators but by enlarging the denominator.

By contrast, given the strongly cyclical pattern of debtors' distress in the past, the historically high levels of business indebtedness outstanding as of the end of the 1980 s suggest that the onset of a major new business recession under these circumstances could easily lead to debt service problems of a kind that would, in turn, further magnify the initial contractionary movement in nonfinancial economic activity. In the event of a recession causing reduced earnings and depressed asset values generally - that is, a recession typical of those that have accompanied all disinflations during the postwar period - - the possibility of financial instability that would compound an already deteriorating economic situation is entirely plausible.

Two principal implications follow. First, in the event of a business contraction initiated by some external factor - - for example, an international cartel action comparable to the oil price increases imposed by OPEC in 1973 and again in 1979 - - the U.S. economy would exhibit less resilience, and correspondingly more proclivity to contractionary dynamics, because of the greater potential for financial instability. But second, to the extent that U.S. policymakers are aware of this potential instability, and that they can and do exert influence over the path of aggregate economic activity, the onset 
of a major business recession is itself less likely. Given the important role of monetary policy in bringing about (or at least not resisting) each of the most significant postwar U.S. recessions, this implication for the likely future behavior of monetary policymakers is probably the more important of the two.

After all, the basic rationale motivating the creation of the Federal Reserve System in the first place was presisely a recognition of the connection between financial instability and nonfinancial economic activity, a connection that was especially visible in the immediately prior downturns of 1907 and 1913. The System's initial purpose, stated clearly in the 1913 Federal Reserve Act, was not to restrict money growth so as to ensure price stability, but just the opposite: "to provide an elastic currency," so as to avoid further financial crises. Indeed, it was the Federal Reserve's failure to act successfully to this end during the early 1930 s that led to the decentralization of a part of its lender-of-last-resort responsibilities to new institutions like the Federal Deposit Insurance Corporation.

As of the outset of the 1990s, the Federal Reserve is likely to be especially sensitive to its responsibilities along these lines not only because of the increased levels of business indebtedness documented in section II but also because of the precarious position of much of the U.S. financial intermediary system. Wholly apart from the problems of the thrift industry, which have already received ample attention elsewhere, the commercial banking industry -- for which the Federal Reserve, as the foremost among bank regulatory authorities, takes a special responsibility -- would also be at great risk in the event of widespread business default.

of the nearly $\$ 3$ trillion in assets and deposits outstanding as of September 1988 at all U.S. commercial banks of size greater than $\$ 50$ million, 
nearly one-third - - almost $\$ 1$ trillion -. was at banks with capital-asset ratios below $6 z$, and in some cases far below, even with all bank assets counted at full book value. ${ }^{18}$ What makes this situation even more sensitive is the concentration of these assets and deposits among the nation's largest banks. Individual banks' yearend data for fiscal years ending in 1988 showed a total of $\$ 833$ million of assets held by the largest 15 banks. ${ }^{19}$ Again with all bank assets counted at full book value, these banks had capital-asset ratios ranging from 1.498 to 6.898 , and an average capital-asset ratio for al1 15 banks (weighted by assets) of 4.348. But merely assuming a reserve for LDC loan losses equal to 50 of each bank's exposure reduced the average capital-asset ratio for the group to $3.17 \%$. For the more exposed banks the erosion consequent on allowing a 50 reserve against LDC loans was even greater. Four of the largest 15 banks had capital-asset below 2 on this basis.

Further, the nation's largest banks are also among the most heavily committed to financing leveraged buy-outs and other corporate reorganizations involving the substitution of debt for equity capitalization. As of the most recent available data, 12 of the 15 largest banks had more than $\$ 1$ billion each in LBO exposure alone, including loans already outstanding plus unfunded commitments. Total LBO exposure among these 12 amounted to $\$ 37$ billion -. more than their combined total capital, even including all LDC loans at full book value. ${ }^{20}$

Because other lenders (life insurance companies, for example) have also participated heavily in financing corporate reorganizations, while most developing countries have been able to borrow only from banks, banks' total LBO exposure remains well below their total LDC exposure. Nevertheless, exposure to risk via LBO debt and other high-leverage corporate situations has grown to 
a magnitude that also represents a potential problem in the event of any systemic default experience. Moreover, the circumstances under which large numbers of highly levered U.S. corporations would be unable to meet their obligations - - a severe business recession, for example - overlap considerably with circumstances under which many developing countries would find servicing their debts even more problematic than is already the case.

The main conclusion, therefore, is that because of the increased likelihood of debtors' distress in the event of an economic downturn, together with the risks to the banking system should an episode of widespread debtors' distress materialize, the Federal Reserve is likely to be less willing either to seek or to permit a business recession in the United States. At the relevant margin of policy choice, U.S. monetary policymakers are likely to perceive the real costs of a business recession - - again, costs in terms of foregone output, incomes, jobs, capital formation, and so on - as greater than would be the case without the higher levels of business indebtedness. On average over an extended period, therefore, U.S. monetary policy is likely to be more expansionary than it would be in the absence of higher debt levels.

A further development of the 1980s that has made this bias in U.S. monetary policy harder to resist is the disappearance of any reliable anchor to the monetary policy process itself. Previously conventional relationships connecting the growth of money or credit aggregates to the growth of income or prices have broken down. 21 Indeed, while there is still a statistically significant correlation between the rate of money growth and the rate of price inflation when both are calculated in the way suggested by Milton Friedman (using two-year moving averages to eliminate short-run fluctuations, and with a two-year lag between the money growth and the inflation), for sample periods 
ending after the early 1980s that significant correlation is negative -- hardly a reasonable basis for making monetary policy.

Nor surprisingly, the Federal Reserve System has responded to these developments by de-emphasizing money and credit aggregates in the formulation and implementation of monetary policy, and -- for lack of an alternative -relying once again on short-term nominal interest rates. ${ }^{22}$ Under the circumstances, doing so was no doubt appropriate. Even so, the experience under monetary policy conducted in this way in the past provides little assurance that policy will be quick to resist an incipient increase in inflation. 23

As in the past, such an increase could arise either from an adverse shock to the economy from some external source (again, for example, an increase in energy prices), or simply from pushing the economy to operate too close to its limit of resources for too long. Especially given the current highly imperfect state of knowledge about just what that limit is (Is the "full employment" unemployment rate now $6 \%$ ? Could it be 58?), mistakes are certainly no less possible than in the past. Indeed, despite the experience of three decades (1950-80) in which inflation in the United States rose from near-nothing to double digits in part because monetary policy repeatedly erred on the side of allowing the economy to expand beyond its non-inflationary capacity, high administration officials in 1989 criticized the Federal Reserve for -- of all things -. taking the risk of erring on the side of under-expansion.

Although it is theoretically possible to achieve both price stability and steady real growth without the occasional punctuation of economic downturns, nothing in the postwar experience of the United States suggests that doing so is practically feasible. Instead, this experience suggests that if enlarged business indebtedness raises the cost of economic downturns, and hence makes 
policymakers less likely to accept them, it therefore also imparts an inflationary bias. Given the uncertainties about monetary policy that now exist for independent reasons, this bias is likely to meet less resistance than would have been the case some years ago.

To put the point in simple short-hand, the borrowing that U.S. corporations and other businesses have done since the end of the 1981-82 recession has shifted the short-and intermediate-run trade-offs confronting monetary policy - importantly including not just the single set of most likely outcomes under any given set of circumstances, but also the attendant risks -. and it is implausible to expect Federal Reserve policymakers to respond to events as they would have had that shift not occurred. But if the reason why these enlarged debt burdens will not lead to debt deflation or worse is that they have effectively locked the Federal Reserve into a no-serious-recession monetary policy, the record of inflation and business cycles since world War II gives little reason for confidence that the ultimate consequence of increased business indebtedness will not be the return of high inflation. 


\section{Summary of Conclusions}

The increase in indebtedness in the United States since 1980 has been extraordinary. It has involved borrowers of all kinds, both public and private, and it has far outstripped the growth of the U.S. economy. The rapid increase of private debt in particular has aroused concerns about the likelihood of an episode of widespread defaults that might disrupt the orderly functioning of the economy's financial markets and hence have further repercussions on nonfinancial economic activity. The arguments and evidence presented in this paper suggest that these concerns are valid to a certain extent, but that a debt default crisis is not the most likely adverse consequence of the recent increase in private indebtedness. Specifically, this paper offers four principal conclusions.

First, problems of debt service within the private sector are more likely to arise among business borrowers, not households. Households borrowed in record volume in the $1980 \mathrm{~s}$, but also accumulated record volumes of a wide variety of assets. By contrast, businesses, and especially corporations, have used much of the proceeds of their borrowing merely to pay down their own or other firms' equity. As a result, interest payments owed by businesses have risen to postwar record levels compared to either earnings or cash flows. So have business bankruptcies and defaults.

Second, despite these high debt service burdens, debt default on a scale large enough to threaten the financial system as a whole is unlikely in the absence of a general economic downturn. The sharp increase in indebtedness has made U.S. businesses crucially dependent on continued strong earnings growth. But as long as earnings do continue to increase, defaults are likely to remain idiosyncratic, and therefore unthreatening to the economy overall. 
Third, the consequent need to prevent a serious recession - - so as to preclude the possibility of a systemic debt default -. will increasingly constrain the Federal Reserve System's conduct of monetary policy. Whether the central bank has the power to prevent a recession under any given set of circumstances is an open question. But the record of business cycles in the United States since World War II makes clear that no recession has been either deep or lasting without the acquiescence, if not the active influence, of monetary policy. The Federal Reserve's reluctance to risk a situation of spreading business (and LDC) debt defaults, especially with the U.S. commercial banking system in its current exposed position, will increasingly prevent it from acquiescing in a recession, much less bringing one about on its own initiative. The resulting expansionary bias in monetary policy over time will be harder to resist, or even identify, because of the breakdown of previous relationships connecting the growth of money and credit to the growth of income and prices.

Fourth, over time this no-serious-recession constraint will severely limit the ability of monetary policy to contain or reduce price inflation. Episodes of disinflation in the United States since World War II have invariably involved business recessions, including declines in business earnings and increases in bankruptcies and defaults. If the economy's financial system has become too fragile to withstand any but the shortest and shallowest recession, it is unlikely to be able to support a genuine attack on inflation. The most likely consequence of a continuation of the recent rise in business indebtedness is therefore to render U.S. nonetary policy increasingly impotent either to reduce inflation from the current level or to resist a renewed acceleration of inflation should it occur. 


\section{Footnotes}

*This paper was written for a meeting of the Group of Thirty, September 28-29, 1989, in New York City. It draws in part on my earlier research, referenced below. I am grateful to Thierry Wizman for research assistance and to the National Science Foundation, the General Electric Foundation and the Harvard Program for Financial Research for supporting my research on this subject.

1. See, for example, Samuelson and Solow (1960), U.S. Council of Economic Advisers (1962), and Gordon (1972).

2. In Okun's terminology, which subsequently became standard, a "point-year" of unemployment is one percentage point of unemployment, in excess of the rate that corresponds to "full employment," maintained for one year.

3. See, for example, Lucas $(1972,1973)$ and Sargent and Wallace (1975).

4. It is striking that the actual experience was so close to Okum's median estimate in that, while subsequent evidence has suggested that a major part of the disinflation was a result of the 748 trade-weighted appreciation of the dollar between 1980 and early 1985, the models surveyed by okun either excluded such currency effects altogether or assigned them little importance. See, for example, Sachs (1985) for an analysis of the effect of dollar appreciation on U.S. disinflation during this period.

5. As is well known, in some episodes since World War II - - for example, the recessions in 1969-70 and 1980 -- the increase in nominal interest rates barely exceeded the increase in inflation, so that the corresponding increase in real interest rates was small. From the perspective of borrowers' ability to meet their commitments in the short run, however, the nominal interest rate is the more important.

6. This section draws in part on Friedman (1986, 1988a, 1989). See also Kaufman (1986a, 1986b).

7. See Friedman (1988b) for a discussion of the sources and consequences of the federal budget deficit in the 1980s.

8. These data value liabilities and debt assets at par, reproducible tangible assets at reproduction cost, and land at market.

9. See, for example, Jensen (1984, 1986, 1988).

10. Yearend values are taken directly from the Federal Reserve System's Flow-of-Funds Accounts, Values for other dates are based on interpolation or extrapolation of the corporate borrowing data in the Flow-of-Funds Accounts, in conjunction with a simple equation that relates the Standard $\&$ Poor's stock price index to the Flow-of-Funds estimate of the market value of equity for the entire nonfarm nonfinancial corporate business sector. 
11. See Friedman (1986) for a brief examination of the Federal Reserve's 1983 Survey of Consumer Finances from this perspective.

12. Data are from Dun and Bradstreet.

13. See, again, Jensen (1984, 1986, 1988).

14. See, for example, Altman and Nammacher (1985) and subsequent annual issues.

15. See Asquith et al. (1989), Table 2.

16. Standard references include Sprague (1910), Fisher (1933), Hart (1938) and Minsky (1963, 1964). See Bernanke (1983) for a more recent evaluation of the evidence from the 1930 s experierce.

17. The classic reference on the origin of financial crises, with particular emphasis on the role of speculation, is Kindleberger (1978).

18. See Brumbaugh et al, (1989), Table 5. Risk-adjusted capital consists of equity capital plus perpetual preferred stock plus subordinated debt and limited preferred stock minus investments in unconsolidated subsidiaries.

19. See the sumnary in Brumbaugh et al., Table 6 .

20. See Quint (1989).

21. See, for example, the evidence in Friedman and Kuttner (1988).

22. In his July 1989 Humphrey-Hawkins testimony before the House Banking Committee (Subcommittee on Domestic Monetary Policy), Chairman Alan Greenspan stated, "In view of the apparent variability, particularly over the short run, in the relationships between the monetary aggregates and the economy, policy will continue to be carried out with attention to a wide range of economic and financial indicators. . . [T] he monetary aggregates may not be preeminent on this list."

23. See Friedman (1988c). 


\section{References}

Altman, Edward I., and Nammacher, Scott A. The Anatomy of the High Yield Debt Market. New York: Morgan Stanley, 1985.

Asquith, Paul, Mullins, David W., Jr., and Wolff, Eric D. "Original Issue High Yield Bonds: Aging Analyses of Defaults, Exchanges, and Calls." Journal. of Finance, 43 (September, 1989), 923-952.

Bernanke, Ben S. "Nonmonetary Effects of the Financial Crisis in the Propagation of the Great Depression." American Economic Review, 73 (June, 1983), 257-276.

Bernanke, Ben S., and Campbe11, John Y. "Is There a. Corporate Debt Crisis?" Brookings Papers on Economic Activity (No.1, 1988), 83-125.

Blair, Margaret M., and Litan, Robert E. "Explaining Corporate Leverage and LBO Activity in the 1980s." Mimeo: Brookings Institution, 1989.

Brumbaugh, R. Dan, Jr., Carron, Andrew S., and Litan, Robert E. "Cleaning Up the Depository Institutions Mess." Brookings Papers on Economic Activity (No. 1, 1989), $243-284$.

Council of Economic Advisers. Annual Report. Washington: U.S. Government Printing Office, 1962.

Fisher, Irving. "The Debt-Deflation Theory of Great Depressions." Econometrica, 1 (October, 1933), 337-357.

Friedman, Benjamin M. "Increasing Indebtedness and Financial Instability in the United States." In Debt. Financial Stability, and Public Policy.

Kansas City: Federal Reserve Bank of Kansas City, 1986.

Friedman, Benjamin M. "The Corporate Debt Problem." In Irving (ed.), Economic Vulnerabilities: Challenges for Policymakers. Washington: Curry

Foundation, 1988a.

Friedman, Benjamin M. Day of Reckoning: The Consequences of American Economic Policy Under Reagan and After. New York: Random House, 1988b.

Friedman, Benjamin M. "Lessons on Monetary Policy from the 1980s." Journal of Economic Perspectives, 2 (Summer, 1988c), 51-72.

Friedman, Benjamin M. "Views on the Likelihood of Financial Crisis." Mimeo: National Bureau of Economic Research, 1989.

Friedman, Benjamin M., and Kuttner, Kenneth N. "Money, Income and Prices After the 1980s." Mimeo: National Bureau of Economic Research, 1988.

Friedman, Milton, and Schwartz, Anna J. A Monetary History of the United States. 1867-1960. Princeton: Princeton University Press, 1963. 
Gordon, Robert J. "Wage-Price Controls and the Shifting Phillips Curve." Brookings Papers on Economic Activity (No.2, 1972), 385-341.

Hart, Albert Gallord. Debts and Recovery. New York: Twentieth Century Fund, 1938 .

Jensen, Michael C. "Takeovers: Folklore and Science." Harvard Business Review, 62 (November-December, 1984), 109-121.

Jensen, Michael C. "Agency Costs of Free Cash Flow, Corporate Finance and Takeovers." American Economic Review, 76 (May, 1986), 323-329.

Jensen, Michael C. "Takeovers: Their Causes and Consequences." Journal of Economic Perspectives, 2 (Winter, 1938), 21-48.

Karfman, Henry. Interest Rates, the Markets, and the New Financial World. New York: Times Books, 1986a.

Kaufman, Henry. "Debt: The Threat to Financial Stability." In Debt. Financial Stability, and Public Policy. Kansas City: Federal Reserve Bank of Kansas City, 1986b.

Kindleberger, Charles P. Manias, Panics and Crashes: A History of Financial Crises. New York: Basic Books, 1978.

Lucas, Robert E., Jr. "Some International Evidence on Output-Inflation Tradeoffs." American Economic Review, 63 (June, 1973), 326-334.

Lucas, Robert E., Jr. "Expectations and the Neutrality of Money." Journal of Economic Theory, 4 (April, 1972), 103-124.

Minsky, Hyman P. "Can 'It' Happen Again?" In Carson (ed.), Banking and Monetary Studies. Homewood: Richard D. Irwin, 1963.

Minsky, Hyman P. "Financial Crisis, Financial Systems, and the Performance of the Economy." In Commission on Money and Credit, Private Capital Markets. Englewood Cliffs. Prentice-Hall, 1964.

Okun, Arthur M. "Efficient Disinflationary Rules." American Economic Review, 68 (May, 1978), 348-352.

Quint, Michael. "Banks Cast a Hard Eye on Buyouts." The New York Times (September 10, 1989), Section 3, 1-14.

Sachs, Jeffrey D. "The Dollar and the Policy Mix: 1985." Brookings Papers on Economic Activity (No. 1, 1985), 117-185.

Samuelson, Paul A., and Solow, Robert M. "Analytical Aspects of Anti-Inflation Policy." American Economic Review, 50 (May, 1960), 177-194.

Sargent, Thomas J., and Wallace, Neil. "'Rational' Expectations, the Optimal Monetary Instrument, and the Optimal Money Supply Rule." Journal of Political Economy, 83 (April, 1975), 241-254.

Sprague, O.M.W. History of Crises under the National Banking System.

Washington: U.S. Government Printing Office, 1910. 